\title{
Case Repert (Polymyositis and Interstitial Lung Disease associated with renal involvement)
}

\author{
Jafar Al-Momani, Khalid Al-Nadi, Kher Mbeidin, Moh'd Najada, Abdullah Al- \\ Omari \\ Pulmonary Division, Medicine Department, King Hussein Medical Center, Amman- \\ Jordan.
}

\begin{abstract}
Polymyositis with interstitial lung disease, renal involvement and positive Anti-Jo-1 antibodies in a 39-year-old male is reported. He presented with cough, dyspnoea and proximal muscle weakness. Chest imaging by X-ray and CT-scan showed wide spread reticulo-nodular densities. Urine analysis revealed RBCs Casts and albumiuria. Open lung biopsy revealed Non-specific interstitial pneumonia and muscle biopsy confirmed the diagnosis of polymyositis. Treating the patient with Prednisolone and Azathioprine showed dramatic improvement.
\end{abstract}

\section{Introduction}

Polymyositis $(\mathrm{PM})$ is an idiopathic inflammatory myopathy with symmetric proximal muscle weakness, elevated skeletal muscle enzyme levels, and characteristic electromyography (EMG) and muscle biopsy findings. The reported incidence of ILD in polymyositis/dermatomyositis varies between $5 \%$ and $46 \%$ in earlier crosssectional studies, depending on whether clinical, radiologic, functional, or pathologic criteria have been used. Renal manifestations include intrinsic renal disease which is very rare. Occasionally, severe rhabdomyolysis with myoglobinuria can result in acute tubular necrosis. 39yr old male patient smoker 20 pack year with no previous medical illnesses, hospitalized in a peripheral hospital complaining of cough, dyspnoea and low grade fever diagnosed as a case of pneumonia given intravenous antibiotic and discharged after one week. Three weeks later patient was admitted to our hospital complaining of cough dyspnoea and lower limb weakness. His physical examination showed diffuse bilateral end inspiratory crackles on chest examination and proximal muscle weakness of the lower limbs and lower limbs oedema.

His chest $\mathrm{X}$ - ray showed bilateral lung infiltrates, and his laboratory data shown in (table 1). 
Table 1

\begin{tabular}{|c|c|}
\hline WBC & 13.500 \\
\hline PCV & 38 \\
\hline Platelets & 355000 \\
\hline \multicolumn{2}{|l|}{$\begin{array}{l}\text { KFTs } \\
\text { Normal }\end{array}$} \\
\hline \multicolumn{2}{|l|}{$\begin{array}{l}\text { Ca. } \\
\text { Normal }\end{array}$} \\
\hline \multicolumn{2}{|l|}{$\begin{array}{l}\text { Phos. } \\
\text { Normal }\end{array}$} \\
\hline $\begin{array}{l}\text { Serum Alb. } \\
\text { g/L }\end{array}$ & 28 \\
\hline $\begin{array}{l}\text { AST } \\
\text { U/L }\end{array}$ & 922 \\
\hline $\begin{array}{l}\text { ALT } \\
\text { U/L }\end{array}$ & 205 \\
\hline $\begin{array}{l}\text { LDH } \\
\text { U/L }\end{array}$ & 2141 \\
\hline $\begin{array}{l}\text { CPK } \\
\text { U/L }\end{array}$ & 9881 \\
\hline $\begin{array}{l}\text { ANA, ANCA, RF } \\
\text { ve }\end{array}$ & - \\
\hline Anti- jo-1 & + ve \\
\hline $\begin{array}{l}\text { Abd. U/S } \\
\text { Normal }\end{array}$ & \\
\hline $\begin{array}{l}\text { Cardiac echo } \\
\text { Normal }\end{array}$ & \\
\hline $\begin{array}{l}\text { PFT } \\
\text { Restrictive Pattern }\end{array}$ & \\
\hline $\begin{array}{l}\text { DLco } \\
\mathbf{5 0 \%}\end{array}$ & \\
\hline $\begin{array}{l}\text { ABGs } \\
\text { Hypoxemia }\end{array}$ & \\
\hline hematuria with RBCs & $\begin{array}{r}\text { Urinalysis } \\
\text { casts and abuminuria } \\
800 \mathrm{mg} / 24 \text { hours }\end{array}$ \\
\hline
\end{tabular}

High resolution chest CT-scan was done (picture1) showed bilateral lung infiltrates with reticulation. Video assist thoracoscopic lung biopsy was done revealed Non specific interstitial pneumonia (picture 2). Muscle biopsy was performed which confirm the diagnosis of polymyositis Patient started on Prednisolone $1 \mathrm{mg} / \mathrm{kg}$ then tapering dose and Azathioprine , he expressed significant improvement clinically and radiologically, his laboratory test three months after treatment shown in (table 2) and high resolution chest CT-scan 3months after treatment (picture 3) and 6month after treatment (picture 4) 
Table 2

\begin{tabular}{ll}
\hline Dlco & $\mathbf{7 5} \%$ \\
\hline PFT & Normal \\
CBC & Normal \\
KFTs & Normal \\
Serum Albumin & 35 g/L \\
AST & NORMAL \\
ALT & NORMAL \\
LDH & NORMAL \\
CPK & NORMAL \\
fasting blood sugar & 182 \\
Urinalysis & NIL RBCs, NIL \\
ALBUMIN,+VE SUGAR \\
\hline
\end{tabular}

\section{Discussion}

Polymyositis (PM) is an idiopathic inflammatory myopathy with symmetric proximal muscle weakness, elevated skeletal muscle enzyme levels, and characteristic electromyography (EMG) and muscle biopsy findings. Although the initial inciting agent remains unknown, possibilities include virus-mediated muscle injury or microvascular insult leading to release of muscle autoantigens. These autoantigens are then presented to $\mathrm{T}$ lymphocytes by macrophages in the muscle. Activated $\mathrm{T}$ lymphocytes proliferate and release cytokines such as interferon gamma (IFN-gamma) and interleukin 2 (IL-2). IFN-gamma promotes further macrophage activation and release of mediators of inflammation such as IL-1 and tumor necrosis factor-alpha (TNFalpha). Interstitial lung disease (ILD) is a heterogeneous group of non-infectious, non-malignant disorders of the lower respiratory tract, characterized by infiltration of inflammatory cells and interstitial fibrosis. Since the original description of ILD in a case of dermatomyositis by Mills and Mathews ${ }^{1}$ in 1956, the association of ILD with polymyositis/dermatomyositis has been widely accepted.

Renal involvement in patients with polymyositis (PM)/dermatomyositis (DM) is previously thought to be uncommon, but two main types of renal lesion have been described. First, acute tubular necrosis with renal failure related to myoglobulinemia and myoglobulinuria is a well-recognised feature of acute rhabdomyolysis. Second, chronic glomerulonephritis has been infrequently reported in a small group of patients with PM/DM

The clinical manifestations of ILD in patients with polymyositis or dermatomyositis may vary from asymptomatic to severe, rapidly progressive dyspnoea with pulmonary insufficiency and fatal outcome.

Not only the myositis itself but also the immunosuppressive treatment and secondary infections caused by immunosuppressive therapy used in these patients might lead to development of interstitial pneumonia and cause diagnostic and therapeutic dilemma.

Cough and dyspnoea are the most commonly reported symptoms, although ILD is also reported to occur in patients without any clinical overt signs of pulmonary involvement.

Other clinical or laboratory signs should also raise the awareness of a concomitant ILD in patients with polymyositis or dermatomyositis. The strongest predictive factor for ILD in patients with myositis is the presence of positive anti-aminoacyl t-RNA synthetase antibodies, of which the anti-histidyl t-RNA synthetase antibody (anti-Jo-1) is the most frequently found. The reported frequency of ILD in patients with anti- Jo-1 antibodies is more than $70 \%$ 
It has been established that ILD can appear concomitantly with, before, or after the onset of skin or muscle manifestations.

Clinical respiratory symptoms are not reliable signs to detect ILD in patients with myositis, because neither cough nor dyspnoea may be present as early signs.

The most useful tests to diagnose ILD are pulmonary function tests, which typically show a restrictive ventilatory defect with decreased total lung capacity, functional residual capacity, residual volume, forced expiatory volume in 1 second $\left(\mathrm{FEV}_{1}\right)$, and forced vital capacity (FVC), but with a normal or elevated $\mathrm{FEV}_{1} / \mathrm{FVC}$ ratio and a decreased diffusing capacity for carbon monoxide (DLco) Not all of these abnormalities may be found in every patient, however. The most sensitive test seems to be the DLco.

HRCT is now widely used not only for detection of ILD but also for identifying the extent and severity of the disease as well as to discriminate between fibrotic Lung disease and active inflammation in the lungs lung biopsy.

Lung biopsies are not routinely performed in patients with myositis with signs of ILD for diagnostic purposes because of the potential morbidity associated with surgical lung biopsy.

Transbronchial biopsies are rarely helpful in the diagnostic procedures, although they are usually abnormal, because the histopathologic findings are nonspecific

Anti-Jo-1 antibodies could not be used as a diagnostic tool for ILD, but because these auto-antibodies are highly associated with ILD, their presence requires careful evaluation of lung involvement using lung function tests and HRCT

Non specific interstitial pneumonia followed by organizing pneumonia was the most commonly observed histologic pattern inpatient with myositis with ILD.

Patients with BOOP and cellular NSIP tend to have the best prognosis and response to corticosteroid treatment, whereas those with DAD have the worst prognosis. Patients with UIP tend to have an intermediate course.

The optimal treatment for myositisassociated ILD is not known. No published controlled trials exist on the effects of different therapies in polymyositis/dermatomyositis with associated ILD. Thus, available information on treatment efficacy is based on small case series or case reports.

Corticosteroid treatment as a single agent is often not sufficient to cause improvement of ILD. Furthermore, the high doses required over a long period are often associated with severe side effects. Thus, other immunosuppressive agents are often required. The most frequently used drugs with reported beneficial effects on lung function are Cyclophosphamide, Cyclosporine A, Azathioprine, and Methotrexate. The response rate may be higher when treatment is initiated early in the course of the disease, before irreversible changes have developed.

PICTURE 1: showed bilateral lung infiltrates with reticulation 

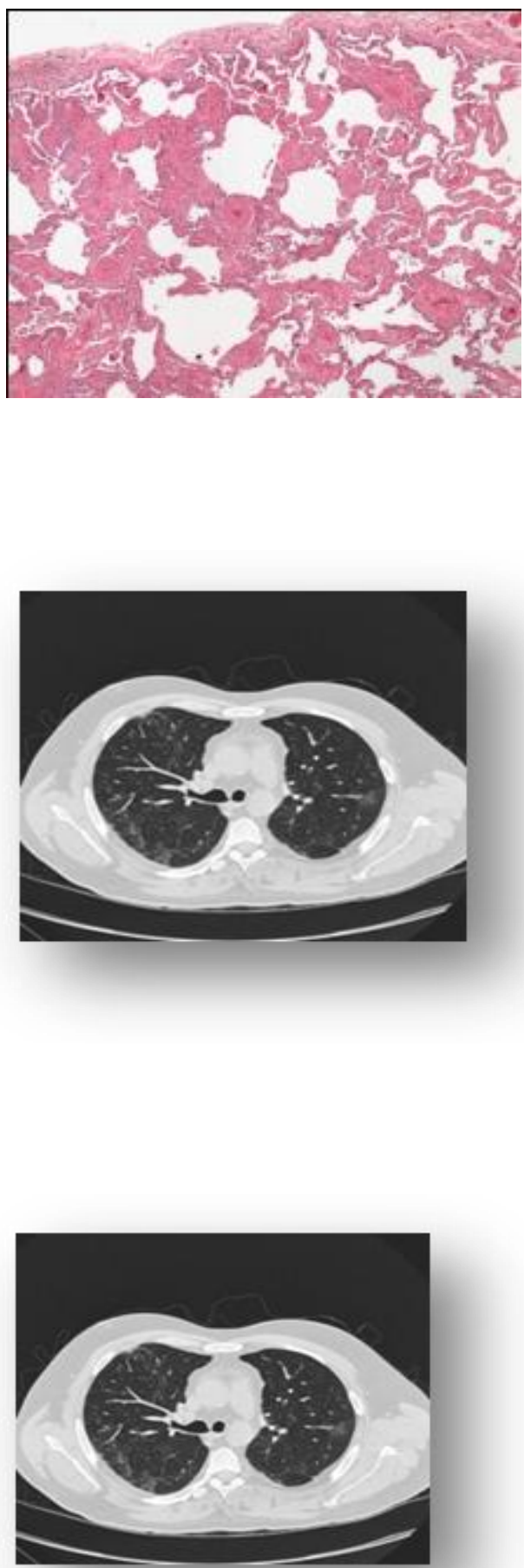

PICTURE 2: Focal areas of diffuse alveolar septal fibrosis extending to the pleural surface were seen - nonspecific interstitial pneumonia.
PICTURE 3: chest CT-scan 3months after treatment. Shows significant improvement with reduce in lung infiltrates and reticulo-nodular shadows

PICTURE 4: 6 months after treatment 
ABBREVIATIONS:

\begin{tabular}{|l|l|}
\hline ALT & Alanine aminotransferase \\
\hline ANA & Antinuclear antibodies \\
\hline ANCA & $\begin{array}{l}\text { Antineutrophil cytoplasmic } \\
\text { antibodies }\end{array}$ \\
\hline AST & Aspartate aminotransferase \\
\hline BOOP & $\begin{array}{l}\text { Bronchiolitis obliterans } \\
\text { organizing pneumonia }\end{array}$ \\
\hline DAD & Diffuse alveolar damage \\
\hline DLCO & $\begin{array}{l}\text { Diffusing capacity for } \\
\text { carbon monoxide }\end{array}$ \\
\hline DM & Dermatomyositis \\
\hline EMG & Electromyography \\
\hline FEV1 & $\begin{array}{l}\text { Forced expiratory volume in } \\
\text { 1 second }\end{array}$ \\
\hline FVC & Forced volume capacity \\
\hline HRCT & $\begin{array}{l}\text { High resolution computed } \\
\text { tomography }\end{array}$ \\
\hline ILD & Interstitial lung disease \\
\hline KFT & Kidney function test \\
\hline NSIP & $\begin{array}{l}\text { Non specific interstitial } \\
\text { pneumonia }\end{array}$ \\
\hline PCV & Packed cell volume \\
\hline PFT & Pulmonary function test \\
\hline RF & Rheumatoid factor \\
\hline RNA & Ribonucleic acid \\
\hline UIP & Usual interstitial pneumonia \\
\hline &
\end{tabular}

\section{References}

- Bjoraker JA, Ryu JH, Edwin MK, et al (1998). Prognostic significance of histopathologic subsets in idiopathic pulmonary fibrosis; Am J Respir Crit Care Med 157:199203.

- Douglas WW, Tazelaar HD, Hartman TE, et al (2001). Polymyositis-dermatomyositisassociated interstitial lung disease. Am J Respir Crit Care Med; 164:1182-1185.

- Fathi M, Dastmalchi M, Rasmussen E, et al (2004). A common manifestation of newly diagnosed polymyositis and dermatomyositis. Ann Rheum Dis., 63:297-301.

- 10 Sakamoto N, Mukae H, Fujii T, et al (2004). Nonspecific interstitial pneumonia with poor prognosis associated with amyopathic dermatomyositis. Intern Med; 43:838-842.

- Marie I, Hachulla E, Cherin P, et al (2002). Interstitial lung disease in polymyositis and dermatomyositis. Arthritis Rheum; 47:614-622.
- Mills ES, athews WH JAMA (1956). Interstitial pneumonitis in dermatomyositis; 160:1467-1470.

- Schnabel A, Reuter M, Biederer J, et al (2003). Interstitial lung disease in polymyositis and dermatomyositis: clinical course and response to treatment. Semin Arthritis Rheum; 32:273-284.

- Schwarz MI (1998). Clin Chest Med The lung in polymyositis ; 19:701-712

- Stephen Chapman, Grace Robinson, John Stradling, Sophie West (2008). Oxford Handbook Of Respiratory Medicine; 22:192-193; 30:262-269

- Tansey D, Wells AU, Colby TV, et al (2004).Variations in histological patterns of interstitial pneumonia between connective tissue disorders and their relationship to prognosis. Histopathology; 44:585-596.

- Tazelaar HD, Viggiano RW, Pickersgill J, et al (1990). Interstitial lung disease in polymyositis and dermatomyositis: clinical features and prognosis as correlated with histologic findings. Am Rev Respir Dis.; 141:727-733. 


\section{التهاب العضلات المتعدد وأمراض الرئة الخلالي المرتبطة بالمشاركة الكلويه الرية}

جفر المومني, خالا النادي, خير المبيضين, محمد النجادا, عبدالله العمري.

قسم الباطنية العامة / الأمر اض الصدرية .

مستشفى مدينة الحسين الطبية الملكية.

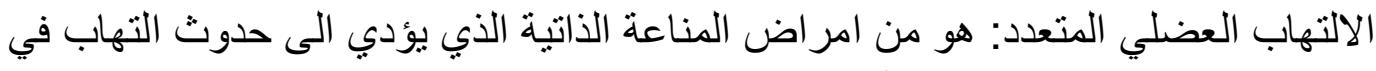

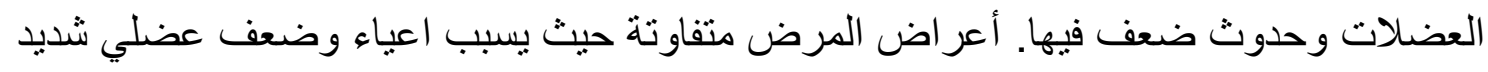

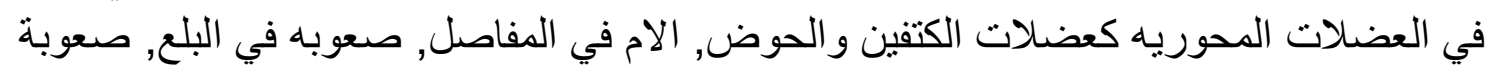

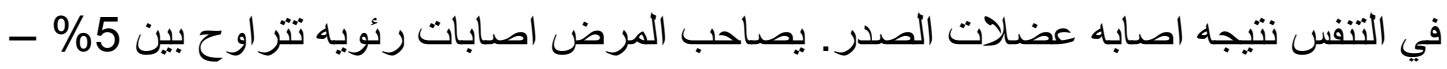

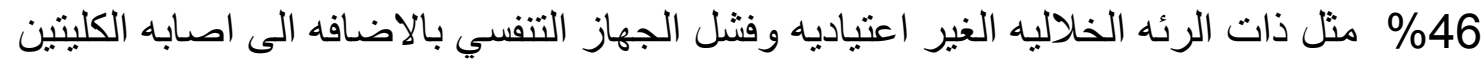

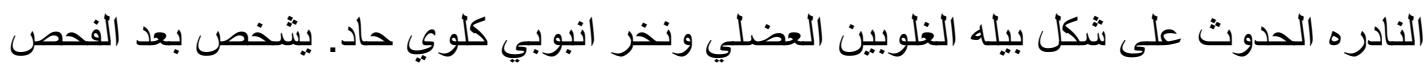

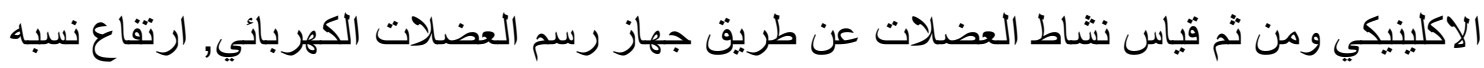
انزيمات العضلات.

ويعتبر اخذ خزعه من النسيج العضلي وفحصها تحت الدجر الاختيار الافضل لتشخيص

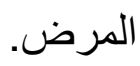

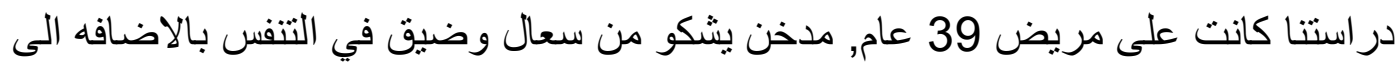

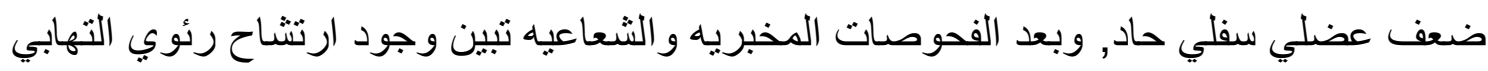

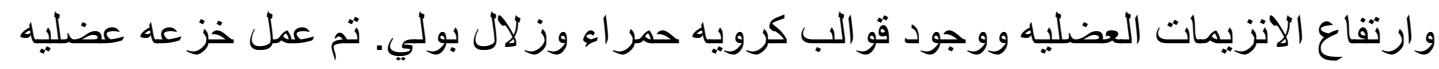
دلت على وجود الالتهاب العضلي المتعدد ووجود ذات الرئه الخلاليه الغير اعتياديه.

المريض عولج بالكورتيكوستيرويدات مع استجابه ملحوظه للعلاج.

الدار اسه تدل على مدى اصابة الرئه و الكليتين عند مرضى الالتهاب العضلي المتعدد و استجابتهم للعلاج. 
